\title{
БАРУУН МОНГОЛЫН ЭРДЭСЖИЛТТЭЙ НУУРУУДЫН УСНЫ ХОРТ ЭЛЕМЕНТИЙН ЭКОГЕОХИМИЙН СУДАЛГАА
}

\author{
Ариунбилэг С. , В.П.Исупов ${ }^{2}$ С.С.Нацкая ${ }^{2}$, А.Г.Владимиров ${ }^{3}$, Е.Н.Мороз ${ }^{3}$ \\ Н.3.Ляхов ${ }^{2,4}$, С.Л.Шварцев ${ }^{5}$ М.Н.Колпакова ${ }^{5}$, Оюун-Эрдэнэ Б $^{6}$ \\ ${ }^{1}$-ШУА-ийн Геологи,эрдэс баялгийн хүрээлэн \\ 2 -ОХУ-ын ШУА-ийн СС-ийн Хатуу биеийн хими, механохимийн хүрээлэн \\ 3 - ОХУ-блн ШУА-ийн СС-ийн Геологи, минералогийн хүрээлэн \\ ${ }^{4}$-ОХУ-ын Сибирийн салбарын ТэргүҮлэгчдийн Газар, Новосибирск \\ 5 -А.А.Трофимукийн нэрэмжит Томскийн нефть-химийн геологи, геофизикийн хүрээлэн, Новосибирск \\ ${ }^{6}$-ШУА-ийн Геоэкологийн хүрээлэн. Цахим шуудан: ariunbilegsodov@yahoo.com
}

\section{ХУРААНГУЙ}

Монгол, Оросын ШУА-иудын хоорондын 2009-2012 онуудын иинжлэх ухааньы суурь судалгааны хамтарсан төслийн хүрээнд Монгол орны эрдэсжилт ихтэй, шорвог нууруудын микроэлементийн агуулгыг анх удаа судалж, зарим эрдэст нууруудын усанд уран ${ }^{238} \mathrm{U}-1$ мг/л) ба бусад дагалдах ховор элементүүдийн $(\mathrm{Br}, \mathrm{Li}, \mathrm{B}, \mathrm{Sr}, \mathrm{Rb})$ агуулга өндөр байгааг илрүҮлсэн юм. ҮҮнээс гадна Баруун Монгольн эрдэсжилт ихтэй томоохон нууруудылн усанд урантай геохимийн эвшил Үүсгэдэг литий, хүниэл зэрэг хорт элементүүдийн агуулга зөвшөөрөгдөх хэмжээнөөс илүY их байгааг илрүүлэв. Эрдэсжилттэй нууруудын усньы уран ба хорт элементийн микроэлементийн хуримтлал нь тухайн газар нутгийн хүрээлэн байгаа орчны уулын чулуулгын найрлагатай холбоотой үүсдэг. Иймд байгаль дээрхи гадаргын усны хорт элементүYдийн (U,As,Se, Mo, V, Li) экогеохимийн асуудалд анхаарал хандуулах хэрэгтэй болж байна.

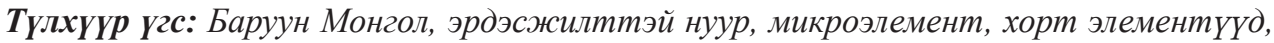
уран, литий, хүнщэлийн агуулга, байгальн ус, геоэкологи

\section{ОРШИЛ}

Сүүлийн жилүүдэд Төв Азийн болон бусад олон оронд эрдэст нууруудын шорвог усан уусмалаас литий, уран, бусад ховор элементүүд /бор, бром, иод/-ийг гарган авч байгаа нь ашигт малтмалын баялгийн нэг шинэ төрөл болон хөгжиж байна. Манай орны эрдэсжилттэй, шорвог нууруудын усны литий, уран болон бусад дагалдах микроэлементийн

гидрогеохимийн судалгааг Монгол Улсын ШУА-ийн Геологи, эрдэс баялгийн хүрээлэн ба Оросын ШУАийн Сибирийн Салбарын Новосибирск хотын Геологи, минералогийн, Хатуу биеийнхими,механохимийнхүрээлэнгуҮдийн хоорондын хамтарсан эрдэм шинжсилээний төслийн хүрээнд 2007 оноос эхэлж хэрэгжүүлж, $ү р$ дүнг эрдэм шинжилгээний хэд хэдэн сэтгүүл $\quad$ хэвлүүлсэн
[1-6]. ЭнэхүY гидрогеохимийн судалгааны үр дүнд Баруун Монголын эрдэсжилттэй зарим давстай нууруудын усны найрлаганд уран, литий, бор, бром, рубидий зэрэг үйлдвэрлэлийн ач холбогдолтой элементүүдийн агуулга их байгааг илрүүлж, тэдгээртэй эвшил үүсгэдэг хүнцэл, молибден, селени зэрэг хортой элементийн агуулга өндөр хэмжээтэй байгааг тогтоов. Эдгээр хорт элементүүдийн агуулга Баруун Монголын эрдэсжилттэй нууруудын уснаас гадна, цэнгэг устай зарим нуурууд, нуурт цутгадаг гол, булаг, худгийн усанд мөн өндөр хэмжээтэй байгааг илрүүлэв. Иймд эрдэсжилттэй нуурууд ба цэнгэг устай нуурууд, голын усны микроэлементийн судалгаанд анхаарал хандуулж, цаашид геоэкологийн асуудлыг шийдвэрлэх нь 
чухал ач холбогдолтой гэж үзлээ.

\section{СУДЛАГДСАН БАЙДАЛ,}

\section{СУДАЛГААНЫ ТАЛБАЙ}

Манай орны нутагт Дэлхийн усны ай савын Төв Азийн гадагш урсацгүй эрдэсжилт ихтэй давстай нуурууд өргөн тархалттай. Монгол орны эрдэст нууруудын гидрогеологи, гидрохимийн судалгаанууд 1961 оноос хойш нилээд хийгдсэн боловч нуурын усны химийн найрлага, хэмжээ, нуурын давс, түүнийг ашиглах талаар голлон анхаарч [Лувсандорж, 1973; Рассказов, 1991; Цэрэнсодом, 2000; Писарский, 2003], нуурын усны микроэлементийн (уран, хүнцэл, литий, бор, бром, болон бусад) судалгаа бараг хийгдээгүй ба сүүлийн жилүүдэд Мөнгөнцэцэг нар Баруун Монголын зарим бүс нутгийн гадаргын усны гидрохимийн судалгааг явуулсан [Мөнгөнцэцэг нар., 2011] байна.

Монгол Улсын ШУА-ийн Геологи, эрдэс баялгийн хүрээлэн ба Оросын ШУА-Сибирийн Салбарын Новосибирск хотын Геологи, минералогийн хүрээлэн, Хатуу биеийн хими, механохимийн хүрээлэнгийн хамтарсан эрдэсжилттэй нууруудын микроэлементийг судлах гидрогеохимийн судалгаагаар манай орны эрдэст нуурын өмнөх судалгааны ажлууд болон монгол орны эрдсээр баялаг нууруудын онцлог, тархалтын зүй тогтлыг дүгнэж үзээд манай орны эрдэст нуурын хурдсанд (гидроминераль гаралтай $\mathrm{Li}$, $\mathrm{Sr}, \mathrm{Br}, \mathrm{B}, \mathrm{U}$ ) шинэ төрлийн ашигт малтмал Үүсэх тохиромжтой нөхцөлүүд бүрдсэн гэж үзсэн. 2007-2012 онуудад хамтарсан хээрийн судалгааны экспедицийг 5 удаа зохион байгуулж 50 гаруй янз бүрийн гидрогеохимийн найрлагатай нуурын ус, ёроолын хурдасны лаг шаварын дээжлэлтийг хийв. Судалгаанд хамрагдсан нуурын байршилтыг зураг 1-д харуулав.

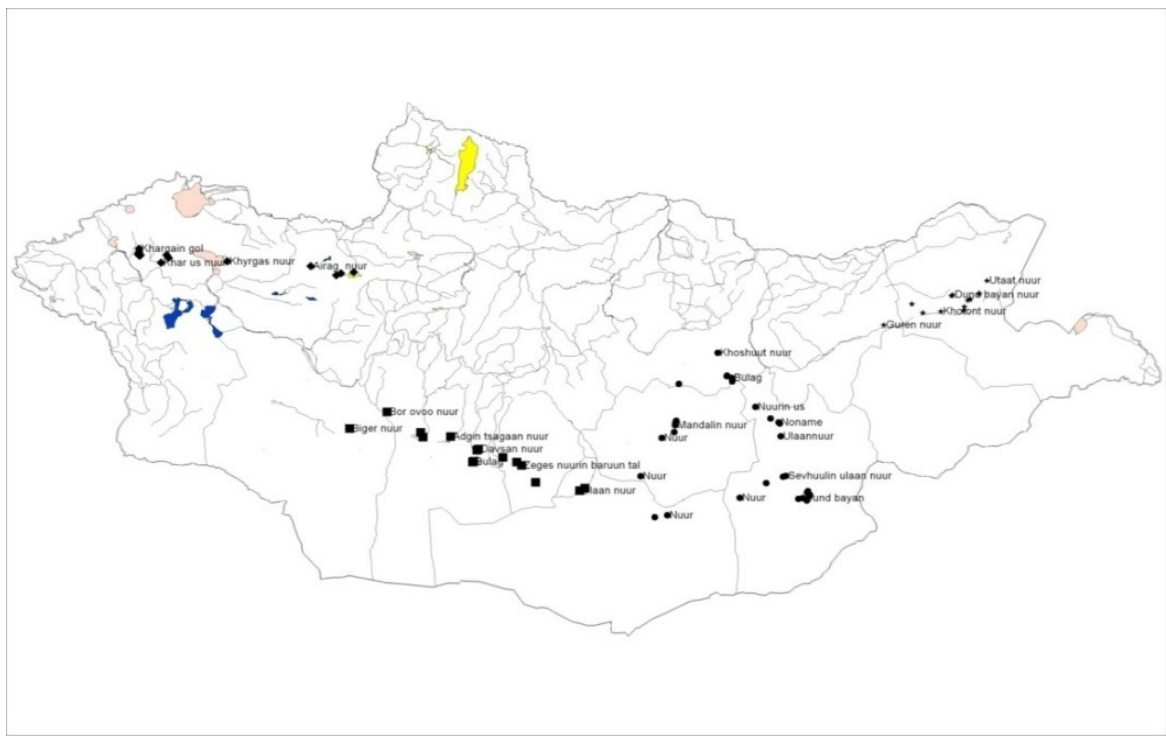

Зураг 1. 2007, 2009-2012 онуудад төслийн судалгаанд хамрагдсан нуррын байршилт

\section{СУДАЛГААНЫ АРГА АРГАЧЛАЛ}

Баруун Монголын эрдэсжилт ихтэй нууруудын химийн найрлага, микроэлементийн судалгаанд 30 гаруй давстай нуурууд хамрагдаж нуурын усны гидрогеохимийн дээжлэлтийг хийж, ОХУын ШУА-ийн СС-ын Хатуу биеийн хими, механохимийн хүрээлэнгийн лабораторид шинжилсэн ( Зураг 2). 


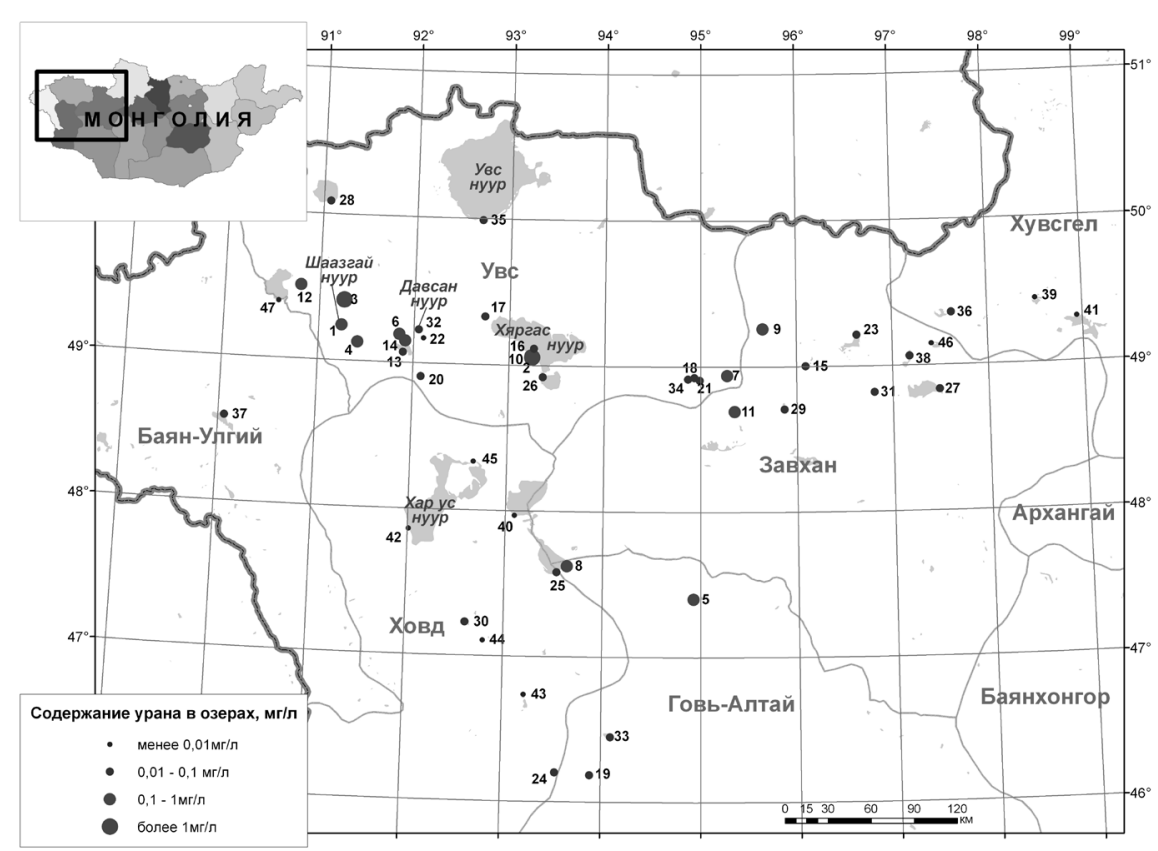

Зураг 2. Баруун Монголын эрдэсжсилттэй нуруудаас гидрогеохимийн дээжслэлт хийсэн цэгҮҮдийн байршилт ба ураны агуулга (Зургийн буланд ураны 0,01-ээс 1 мг/л ба түүнээс их агуулгын хэмэээг харуулав. Нууруудын дэс дугаар нь хүснэгт 1-4-д байгаа шинжсилгээний дүнтэй харгалзана)

Нуурын усны гидрохимийн дээжлэлтийг 30-40 см гүнээс авч газарзүйн байршилт, нуурын усны өндөрлөгийг GPSээр хэмжсэн. Усны микроэлементүүдийн шинжилгээнд зориулж азотын хүчлээр $\mathrm{pH}=1-2$ хүртэл хүчиллэгжүүлнэ. Нуурын эрдэсжилтийн найрлага, уран болон бусад микроэлементүүдийн (As, B, Мо г.м) шинжилгээг индукт-холбоостой плазмын спектрометр Agilent 7500-аap, мөн атомшингээлтийн ИСП (iCAP 6300 Duo, Thermo Scientific) багажаaр тодорхойлсон. Нуурын усны эрдэсжилтийн хэмжээ, химийн найрлага дахь катион $\mathrm{Na}, \mathrm{K}$, $\mathrm{Ca}, \mathrm{Mg}, \mathrm{Sr}, \mathrm{Li}$-ийн агуулга болон хлор, карбонат, гидрокарбонат, сульфатын ионы агуулгыг Сатурн-2 М и Varian AA 280 FS спектрометрийн багаж дээр тус тус тодорхойлов.

\section{СУДАЛГААНЫ АЖЛЫН ҮР ДҮН}

Баруун Монголын эрдэсжилттэй нууруудын усны химийн найрлага, микроэлементийн шинжилгээ хийж шинжилгээний үр дүнгээр өгүүлэл бичиж хэвлүүлсэн билээ [3,5,7 ]. Бидний өмнөх жилҮҮдийн судалгаагаар Баруун Монгольнн Их Нууруудын хотгорын плейстоценнеогены хотгорын 1050 м-ээс дээш өндөрлөгт оршдог томоохон нууруудын усны найрлаганд анионаас карбонатын ион (0,4-600 мг/л), гидрокарбонатын ион (290$2500 \mathrm{Mг} / л)$ давамгайлж катионы харьцаагаар натри, калийн ион зонхилж, тэдгээр нуурууд нь давс, хужирын эрдэсжилтэй ба зарим нуурын усанд магнийн ион ихсэж эрдэсжилт нэмэгдэж, усны рН -7.4-9.4 хүрч байна. Их Нууруудын хотгорын нууруудын усан дахь натрий, калийн карбонатын ионуудтай харилцан хамааралтай ураны $\left({ }^{238} U\right)$ агуулга 0,01-1.1 мг/л хүртэл хэлбэлзэж $\mathrm{UO}_{2}\left(\mathrm{CO}_{3}\right)_{2}{ }_{2-}, \mathrm{UO}_{2}\left(\mathrm{CO}_{3}\right)_{3}{ }_{3}^{4-}, \mathrm{UO}_{2}\left(\mathrm{CO}_{3}\right)^{0}$ гэх мэт карбонат уранилийн нэгдэлүҮд үүсч байна. Мөн үүнээс гадна бор (>100 мг/л), бром (>460 мг/л), литий (>50 мг/л), стронции 
(>8 мг/л) -ийн агуулга өндөр болж байна. Шаазгай нуурын усанд дээрхи элементээс гадна мыщъякийн агуулга их байгаа нь нуурын усыг экологийн хор нөлөөтөй гэдгийг харуулж байна. Ураны өндөр агуулга нууруудын усны натри, хлор, бикарбонит, карбонат ион, $\mathrm{pH}$, хүнцэлтэй эерэг хамааралтай бөгөөд харин нуурын усны магний, кальций, калийн катион, сульфатын ионтой эсрэг хамааралтай хуримтлагдаж байгааг илрүүлэв. Нуурын усанд агуулагдах уран, литийн агуулга тухайн газар нутгийн эргэн тойрны уулын чулуулгийн тогтоц, найрлагаас нилээд их хамааралтайг тогтоов $[3,7]$.

Энэ хугацаанд Баруун Монголын эрдэсжилттэй нууруудын усны уран, литийн агуулга хэвийн хэмжээнээс нилээд их агуулагдаж байгааг илрүүлэхээс гадна

уран литий, хүнцэл, хүнд металл болох хар тугалга, селени кадмии зэрэг байгаль орчны бохирдлыг үүсгэдэг хортой элементүүдийн агуулга их байгааг тогтоосон юм. Эдгээрээс уран, хүнцэл, литийн агуулгыг онцолж ураны агуулгын хэмжээгээр эрдэсжилттэй нууруудыг ангилж хүснэгт 1-5-д үзүүлэв.

Судалгаанд хамрагдсан нууруудаас $\mathbf{1}$ мг/л -ээс их уран $\left({ }^{238} \mathrm{U}\right)$ агуулсан нуурт Увс аймгийн хужирын найрлагатай Шаазгай нуур ба Хяргас нуурын хотгорт оршдог Бага гашуун зэрэг жижиг нуурууд хамрагдаж, ураныг дагалдаж хүнцэл 0,25 мг/л, литий 0,7-16 мг/л хүртэл агуулга нь ихэсч байна. Энэ нь далайн усан дахь уран(0.0003мг/л), хүнцэл $(0.01 \mathrm{Mг} / л), \quad$ литийн $\quad(0.01 \mathrm{~m} /$ л) агуулгаас хэдэн зуу дахин их агуулагдаж байгааг (Хүснэгт 1) харуулж байна..

Хүснэгт 1 Ураны агуулга нь 1мг/л-ээс их хэмжээтэй нууруудын усны хорт элементийн $\left({ }^{38} \mathrm{U}, \mathrm{As}, \mathrm{Li}\right)$ aгуулга

\begin{tabular}{|c|c|c|c|c|c|c|}
\hline Д/д & Нуурын нэр & $\begin{array}{l}\text { Уран, } \\
\text { мг/л }\end{array}$ & $\begin{array}{c}\text { Хүнцэл, } \\
\text { мг/л }\end{array}$ & $\begin{array}{c}\text { Литий, } \\
\text { мг/л }\end{array}$ & $\begin{array}{c}\text { Дээж } \\
\text { авсан он }\end{array}$ & $\begin{array}{c}\text { Аймгийн } \\
\text { нэр }\end{array}$ \\
\hline 1 & Шаазгай нуур & 1,0 & 0,25 & $1-1,1$ & $2010-2012$ & $\mathrm{Y}_{\mathrm{BC}}$ \\
\hline 2 & Бага-гашуун нуур & $\begin{array}{l}3,0 \\
2,0\end{array}$ & $\begin{array}{l}0,48 \\
-\end{array}$ & $\begin{array}{l}16 \\
10\end{array}$ & $\begin{array}{l}2010 \\
2012\end{array}$ & $\mathrm{Y}_{\mathrm{BC}}$ \\
\hline 3 & $\begin{array}{l}\text { Шаазгай нуур } \\
\text { (Харгайн голын эх) }\end{array}$ & $\begin{array}{l}2,2 \\
2,2\end{array}$ & $\begin{array}{l}0,05 \\
0,004\end{array}$ & $\begin{array}{l}0,7 \\
0,18\end{array}$ & $\begin{array}{l}2011 \\
2012\end{array}$ & $\mathrm{Y}_{\mathrm{BC}}$ \\
\hline
\end{tabular}

Ураны $\left({ }^{238} \mathrm{U}\right)$ агуулга $\mathbf{0 . 1 - э э с ~} 1$ мг/л хүртэл хэмжээгээр Сангийн далай, Цоохор, Бага нуур, Бор хаг нуур, Цавдан, Цагаан нуур, Дэвтээр зэрэг (Хүснэгт 2) уулс хоорондын хотгорт оршдог гадагш урсацгүй нилээд олон нууруудад тогтоогдсон ба тэдгээр нуурт ураны агуулга далайн усны агууламжтай харьцуулахад харьцангүй их ба араваас хэдэн зуу дахин их байгаад анхаарч тэдгээр нууруудын давс, хужирыг олзворлож байгаа нь анхаарал татаж байна. Эдгээр нууруудаас Их нууруудын хотгорын хамгийн нам дор газарт орших Говь Алтай аймгийн Сангийн далай, Цоохор зэрэг шорвог давстай нуурт хүнцэл, литийн агуулга хамгийн өндөр тогтоогдсон ба мөн Хангайн уулархаг мужид байрлалтай Цавдан, Цагаан нуур, Дэвтээр зэрэг эрдэсжилт ихтэй нууруудын усанд мөн агуулга ихсэж байгаа нь ажиглагдав.

Хүснэгт 2.

Ураны агуулга нь 0.1- 1 мг/л хэмэсээтэй нууруудын усны хорт элементийн $\left({ }^{38} \mathrm{U}, \mathrm{As}, \mathrm{Li}\right)$ агуулга

\begin{tabular}{|c|l|c|c|c|c|c|}
\hline Д/д & \multicolumn{1}{|c|}{ Нуурын нэр } & Уран, мг/л & $\begin{array}{c}\text { Хүнцэл, } \\
\text { мг/л }\end{array}$ & $\begin{array}{c}\text { Литий, } \\
\text { мг/л }\end{array}$ & $\begin{array}{c}\text { Дээж } \\
\text { авсан он }\end{array}$ & $\begin{array}{c}\text { Аймгийн } \\
\text { нэр }\end{array}$ \\
\hline 4 & Бор Хаг нуур & 0,460 & 0,089 & 1,5 & 2012 & Увс \\
\hline 5 & Сангийн далай нуур & 0,38 & 1,09 & 3,4 & 2010 & Говь Алтай \\
\hline 6 & Шар бүрд & 0,4 & 0,02 & 0,39 & 2012 & Увс \\
\hline
\end{tabular}




\begin{tabular}{|c|l|c|c|c|c|c|}
\hline 7 & Цагаан нуур & 0,2770 & 0,09 & 1,66 & 2011 & Завхан \\
\hline 8 & Цоохор нуур & 0,247 & 0,42 & 0,19 & 2010 & Говь Алтай \\
\hline 9 & Цавдан нуур & 0,2153 & 0,18 & 1,45 & 2011 & Увс \\
\hline 10 & Их гашун нуур & 0,3 & 0,1 & & 2010 & Увс \\
\hline 11 & Дэвтээрийн Давс нуур & 0,1523 & 0,26 & 1,31 & 2011 & Завхан \\
\hline 12 & Бага нуур & 0,13 & - & 3,5 & 2008 & Увс \\
\hline 13 & Хар ус нуур & 0,1 & 0,08 & 1,1 & 2012 & Увс \\
\hline 14 & $\begin{array}{l}\text { Бага нуур (Өлгий } \\
\text { сумын) }\end{array}$ & 0,110 & 0,12 & 1,2 & 2012 & Увс \\
\hline
\end{tabular}

Их Нууруудын хотгорын олон голын цутгалуудтай томоохон нууруудад уран ба бусад элементийн агуулгын хэмжээ харьцангүй бага байгаа бөгөөд уран $\left({ }^{238} \mathrm{U}\right)$ $\mathbf{0 , 1 - 0 , 0 1}$ мг/л хэмжээтэй агуулагдана (Хүснэгт 3).

Хуснэгт 3.

Ураны агуулга нь 0,1-0,01 мг/л хэмжээтэй нурруудын усны хорт элементийн $\left.{ }^{238} \mathrm{U}, \mathrm{As}, \mathrm{Li}\right)$ агуулга

\begin{tabular}{|c|l|c|c|c|c|c|}
\hline Д/д & \multicolumn{1}{|c|}{ Нууруудын нэр } & $\begin{array}{c}\text { Уран, } \\
\text { мг/л }\end{array}$ & $\begin{array}{c}\text { Хүнцэл, } \\
\text { мг/л }\end{array}$ & $\begin{array}{c}\text { Литий, } \\
\text { мг/л }\end{array}$ & $\begin{array}{c}\text { Дээжлэлт } \\
\text { хийсэн он }\end{array}$ & Аймаг \\
\hline 15 & Айраг нуур & 0,095 & - & 2,00 & 2009 & Завхан \\
\hline 16 & Хяргас нуур & 0,09 & 0,01 & 0,3 & 2012 & Увс \\
\hline 17 & $\begin{array}{l}\text { Бага нуур (Хяргас } \\
\text { нуурын орчимд) }\end{array}$ & 0,063 & - & 0,98 & 2008 & Увс \\
\hline 18 & Олгой нуур & 0,0747 & 0,0444 & 0,084 & 2011 & Завхан \\
\hline 19 & Тонхил нуур & 0,077 & 0,56 & 2,42 & 2010 & Ховд \\
\hline 20 & Өлгий нуур & 0,068 & 0,027 & 0,1 & 2012 & Увс \\
\hline 21 & Тахилт нуур & 0,0550 & 0,1230 & 2,07 & 2011 & Завхан \\
\hline 22 & Судж нуур & 0.0485 & 0,023 & 1,75 & 2011 & Увс \\
\hline 23 & Ойгон нуур & 0,0485 & 0,0178 & 0,55 & 2011 & Завхан \\
\hline 24 & Хулам нуур & 0,047 & 0,24 & 8,94 & 2010 & Ховд \\
\hline 25 & Дөргөн нуур & 0,034 & 0,05 & 0,45 & 2010 & Ховд \\
\hline 26 & Айраг нуур & 0,03 & 0,02 & 0,08 & 2012 & Увс \\
\hline 27 & Тэлмэн нуур & 0,03 & 0,02 & 0,026 & 2011 & Завхан \\
\hline 28 & Үүрэг нуур & 0,026 & - & 0,066 & 2008 & Увс \\
\hline 29 & Цэгэн нуур & 0,0252 & 0,0303 & 0,1650 & 2011 & Завхан \\
\hline 30 & Зэргийн Цаган Нур & 0,023 & 0,019 & 0,04 & 2010 & Ховд \\
\hline 31 & Тахилт нуур & 0,02 & & 0,47 & 2009 & Завхан \\
\hline 32 & Давсан нуур & 0,02 & 0,4 & 90 & 2012 & Увс \\
\hline 33 & Ихэс нуур & 0,02 & 0,32 & 0,02 & 2010 & Ховд \\
\hline 34 & Цагаан нуур & 0,02 & 0,015 & 0,11 & 2011 & Завхан \\
\hline 35 & Увс нуур & 0,017 & 0,019 & 0,18 & 2010 & Увс \\
\hline 36 & Жугнайн нуур & 0,0117 & 0,0107 & 0,049 & 2011 & Хөвсгөл \\
\hline 37 & Толбо нуур & 0,011 & 0,0024 & 0,13 & 2010 & Баян-Өлгий \\
\hline 38 & Холбоо нуур & 0,0107 & 0,0082 & 0,042 & 2011 & Завхан \\
\hline & & & & & \\
\hline
\end{tabular}

Манай орны хамгийн цэнгэг устай томоохон нууруудын усны найрлаганд ураны агуулга хамгийн бага буюу далайн усны хэмжээтэй адилхан тогтоогдсон (Хүснэгт 4). Харин Ховд аймгийн нутаг дахь хойт Хар ус нуурт хүнцэл нилээд өндөр агууламжтай буюу "Усан орчны чанарын стандарт MNS 4586:1998”-д зааснаас 19 дахин их агуулагдаж байгааг тогтоов (Хүснэгт 4). 
Хуснэгт 4.

Ураны агуулга нь 0,01 мг/л-ээс бага хэмжюэтэй нууруудын хорт элементийн $\left.{ }^{238} \mathrm{U}, \mathrm{As}, \mathrm{Li}\right)$ агуулга

\begin{tabular}{|c|l|c|c|c|c|c|}
\hline Д/д & \multicolumn{1}{|c|}{ Нуурын нэр } & $\begin{array}{c}\text { Урана, } \\
\text { мг/л }\end{array}$ & $\begin{array}{c}\text { Хүнцэл, } \\
\text { мг/л }\end{array}$ & $\begin{array}{c}\text { Литий, } \\
\text { мг/л }\end{array}$ & Хугацаа & Аймаг \\
\hline 39 & Тунамал нуур & 0,0097 & 0,0070 & 0,35 & 2011 & Хөвсгөл \\
\hline 40 & Хар нуур & 0,0078 & 0,19 & 0,055 & 2010 & Ховд \\
\hline 41 & Сангийн далай нуур & 0,0056 & 0,0076 & 0,067 & 2011 & Завхан \\
\hline 42 & Хар ус нуур & 0,0052 & - & 0,069 & 2010 & Ховд \\
\hline 43 & Бага нуур (Цэцэг нуур) & 0,0045 & - & 0,051 & 2010 & Ховд \\
\hline 44 & Хөдөө нуур & 0,0034 & - & 0,053 & 2010 & Ховд \\
\hline 45 & Далай нуур & 0,0032 & 0,048 & 0,023 & 2010 & Ховд \\
\hline 46 & Бүст нуур & 0,0032 & 0,0013 & 0,061 & 2011 & Завхан \\
\hline 47 & Ачит нуур & 0,0031 & - & 0,01 & 2008 & Увс \\
\hline
\end{tabular}

Дээрхи шинжилгээний дүнгүүдээс үзэхэд манай орны баруун бүс нутгийн ихэнхи эрдэсжилттэй нууруудад уран ба хүнцэл, литийн агуулга их байгаа ба Дэлхийн далайн дундач ураны агуулга $(0,003$ мг/л) -аас хэд дахин их байна. Ялангуяа Шаазгай, Бага гашуун зэрэг

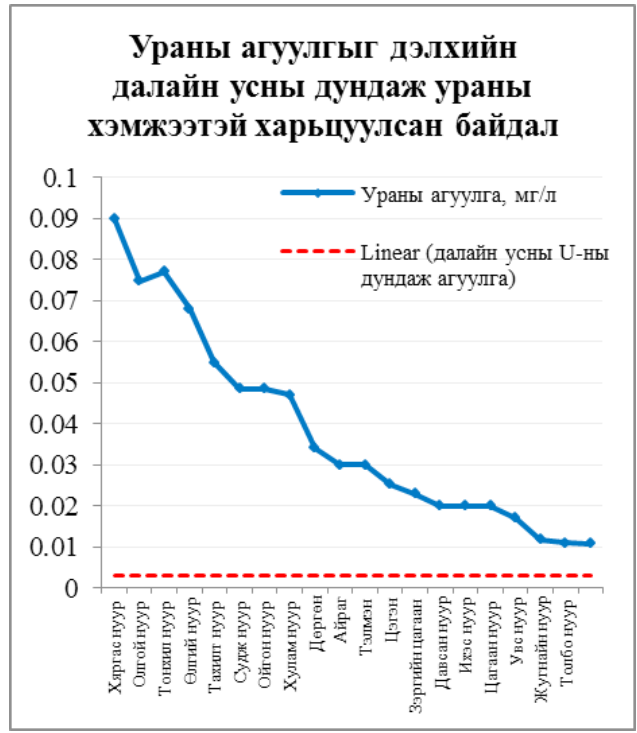

3ypaz 3.

Зарим томоохон нууруудад агуулагдах хүнцэлийн агуулгыг манай орны усан орчны стандарттай харьцуулсан байдлыг зураг 4-д үзүүлэв. Манай улсын "Усан орчны чанарын стандарт MNS 4586:1998"-д зөвхөн хүнцэлийн хэмжээг заасан байгаа ба тус стандарттай харьцуулахад эдгээр цэгүүдэд хужиртай нууруудад зөвшөөрөгдө хэмжээнээс 100 гаруй дахин их байна. Мөн Хяргас, Айраг, Дэвтээр, Хар ус нуур зэрэг томоохон нууруудад ураны агуулга далай, тэнгэсийн усны агуулгаас 10-100 дахин их хэмжээтэй байгааг тогтоолоо (Зураг 3 ).

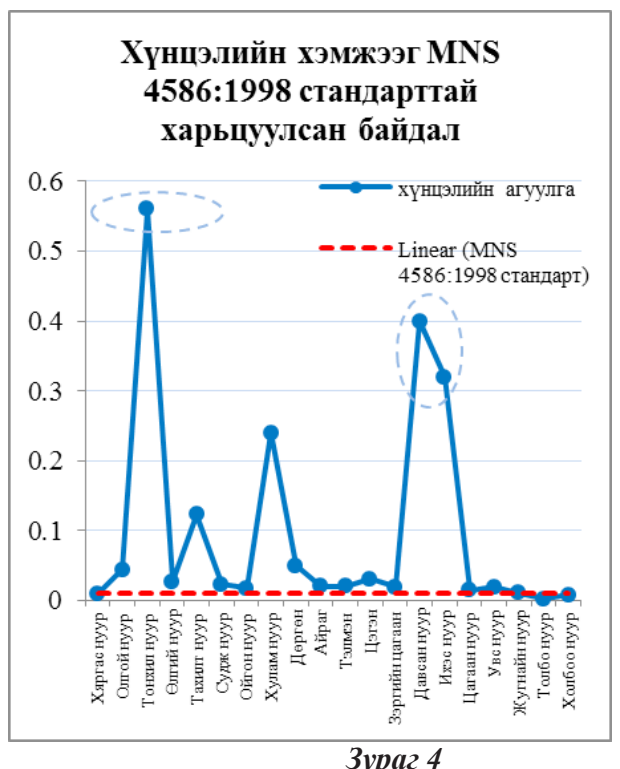

5-48 дахин их байна. Тонхил, Давсан, Ихэс нуур зэрэг эртний хурдсаар хүрээлэгдсэн гадагш урсацгүй шорвог нууруудад уранаас гадна хүнцэлийн хэмжээ хамгийн их байгааг харж болно.

Харин Баруун Монголын Завхан гол, Ховд, Шивэрийн гол, Хүнгий, Намирын 
голууд харьцангуй цэвэршилттэй уран, хүнцэл, литийн агуулга хамгийн бага хэмжээтэй агуулагдаж байна (Хүснэгт 5). Энэ нь манай улсын цэнгэг устай голуудын ус, "Ундны усны MNS 900:2010" стандартад тавигдах уран, хүнцэл, литийн хүлцэх агууламжийн (U-0.015 mg/L , As -0.01, Li-0.01 mg/L) шаардлагыг хангасан ба харин далайн усны хүлцэх агууламжаас харьцангуй их байна.

Хуснэгт 5

Баруун Монголын зарим голын усны хортой элементуҮдийн агуулга $\left({ }^{238} \mathrm{U}, \mathrm{As}, \mathrm{Li}\right)$

\begin{tabular}{|l|c|c|c|c|c|}
\hline \multicolumn{1}{|c|}{ Голын нэр } & Уран, мг/л & Хүнцэл, мг/л & $\begin{array}{c}\text { Литий, } \\
\text { мг/л }\end{array}$ & Он Аймаг \\
\hline Харгайн гол (эхэнд) & $0,0004-0,0006$ & $0,00006-0,00007$ & 0,004 & 2012 & Увс \\
\hline Харгайн гол (дунд хэсэг ) & 0,016 & 0,0002 & 0,076 & 2012 & Увс \\
\hline Завхан гол (гүүрний орчим) & 0,0035 & - & 0,054 & 2010 & Увс \\
\hline Завхан гол (гүүрнээ доош) & 0,0040 & 0,0078 & 0,008 & 2012 & Увс \\
\hline Ховд гол (Ховд сум) & 0,0028 & 0,0081 & 0,009 & 2010 & Увс \\
\hline Шивэр гол (дунд хэсэгт) & 0,0045 & 0,029 & 0,045 & 2010 & Увс \\
\hline Шивэр гол & 0,0002 & 0,0008 & 0,0054 & 2011 & Увс \\
\hline Хүнгий гол (Ургамал сум) & 0,0028 & 0,0010 & 0,0019 & 2012 & Завхан \\
\hline Намирын гол & 0,0024 & 0,0019 & 0,014 & 2011 & Увс \\
\hline Намирын гол & 0,0024 & 0,0038 & 0,029 & 2012 & Увс \\
\hline
\end{tabular}

Уран ба бусад хорт элементийн агуулга зөвхөн нуурын шорвог эрдэсжилттэй нууранд байхаас гадна тэдгээр нуурт цутгадаг булаг, голын байгалийн ус ба гүний усанд мөн бага хэмжээтэй байгааг илрүүлэв. Манай улсын “Ундны усны MNS 900:2010” стандарттай харьцуулахад Увс аймгийн Хяргас нуурын ойролцоо байдаг Завхан сумын гүний худагт ураны агуулга 0,030 мг/л хүрч байгаa нь дээрх стандартад зааснаас 2 дахин их, Хойт могойн булагт болон Хяргас нуурын хойд эргийн худагт 1,87 дахин тус тус их байна.

\section{ХЭЛЭЛЦҮУЛЭГ}

Баруун Монголын томоохон нуурууд, зарим голын усны микроэлементийн агуулга дахь уран, түүнийг дагалдаж үүсдэг хүнцэл, литий зэрэг хорт элементийн бохирдолтын эх, үүсвэр нь маагмын чулуулаг, ашигт малтмалын орд, илрэлүүдтэй холбоотой бөгөөд уулын чулуулгийн элэгдэл, бутралын геологийн үйл явцтай холбож тайлбарладаг. Бидний судалгаагаар Увс аймгийн $\quad\left(\mathrm{N}: 49^{0} 14^{\prime} 38.2^{\prime \prime} . \mathrm{E}: 91^{0} 14^{\prime} 26.7^{\prime \prime}\right)$ Ховд сумын нутагт орших Шаазгай нуурын жишээн дээр нуурын усанд ураны хуримтлагдах явцыг судалж үзсэн [7].
Иймд эдгээр гол, худагны усыг нутгийн ард иргэд хүнсэндээ хэрэглэж байгааг анхаарч цаашид геоэкологийн бүрэн судалгааг явуулж, хүний эрүүл мэндэд эрсдэл байгаа эсэх талаар судлах хэрэгтэй байна.

Баруун Монголын томоохон нууруудын усанд агуулагдах уран, болон түүнтэй эвшил үүсгэдэг хүнцэл, литийн агуулга нь тухайн нуурын байршилт, хүрээлэн орших уулын чулуулгийн найрлага,усны хагалбар газар ба газарзүйн байршилт зэрэгтэй холбож тайлбарлаж байна.

Шаазгай нуур нь харьцангуй өндөрлөгт оршдог (2000м), Хархираагийн шүлтлэг лейкогранит, шүлтлэг рибекиттэй аляскитаас тогтсон интрүзив бүрдлүүд ба түрүү-дунддевоны настай диоритоос аляскит хүртэл найрлагатай шүлтлэг дэл судлуудаас тогтсон уулсаар хүрээлэгдсэн, химийн найрлагаараа карбонатын төрлийн нуурт багтдаг. Энэ нуурт Ёлын булаг ба Харгайн жижиг гол цутгадаг ба гүний усаар тэжээгдэнэ (Зураг 5). 


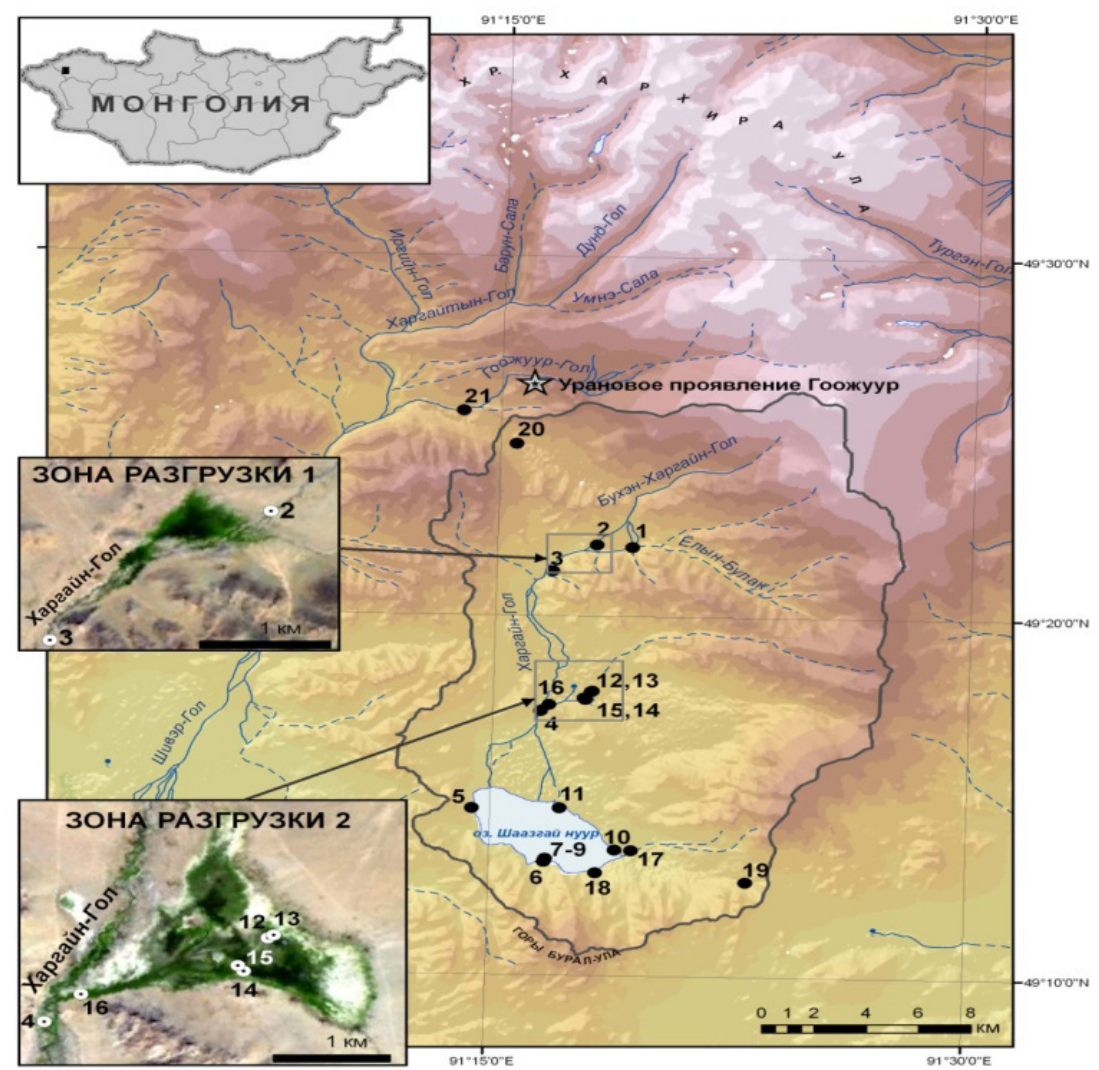

Зураг 5. Увс аймгийн Шаазгай нуурын ус хураагуурын байриилт ба дээжслэлтийн иэгуҮд[7].

Нуурын усны захаас 10 м дотогшлоход гүн нь 75 см болно. Шаазгай нуурын усны эрдэсжилт ба микроэлементийн найрлагыг өмнөх жилүүдийн судалгаагаар хийсэн бөгөөд нуурын усны эрдэсжилт 13560 мг/л, $\mathrm{pH}-9.4$, ба эрдэсжилтийн ихэнхийг бикарбонат натрийн давс эзэлдэг. И.П.Исупов [7] нарын 2010,2011 онуудын судалгааны үр дүнд нуурын усанд ураны хэмжээ $\left({ }^{238} \mathrm{U}-1.0\right.$ мл/л) ихэсч, нуурт цутгаж байгаа Ёлын булгын усанд-0,011мг/л, Харгайн жижиг голын усны эхэнд-0,2 мг/л, голын дунд хэсэгт ураны агуулга- 0,016 мг/л -д, заримдаа ${ }^{238} \mathrm{U}$ харьцангуй их (-0.03 мл/л) агуулагдаж байгааг тогтоосон юм. Харин Шаазгай нуурын ойролцоо орших Хархираагийн шүлтлэг интрүзив бүрдлийн чулуулагтай холбоотой Гоожуурын ураны илрэлд - ураны агуулга 100 г/т, карбоны настай шүлтлэг аляскитад 0,3713,9 г/т байна. Үүнээс харахад Шаазгай нуурын орчмын шүлтлэг чулуулаг, ураны илрэлтэй нягт холбоотой нуурын ус болон байгалийн булаг,голын усанд ураны хуримтлал үүсч байна. Үүнийг манай орны нутаг дэвсгэрийн радиогеохимийн бүсийн зурагтай харьцуулж үзэхэд Баруун Монголын ураны эрдэсжилттэй Хяргас, Шаазгай болон Тэлмэн, Шар бүрд, Цагаан нуур, Цоохор, Цавдан,Их гашуун, Дэвтээр, Хар ус нуур (хойт) зэрэг нуурууд Хангай ба Цагаан шивээт уран агуулсан потенциал мужын радиогеохимийн бүсийг дагасан гүний хагарлууд дээр байршина (Зураг 6). 


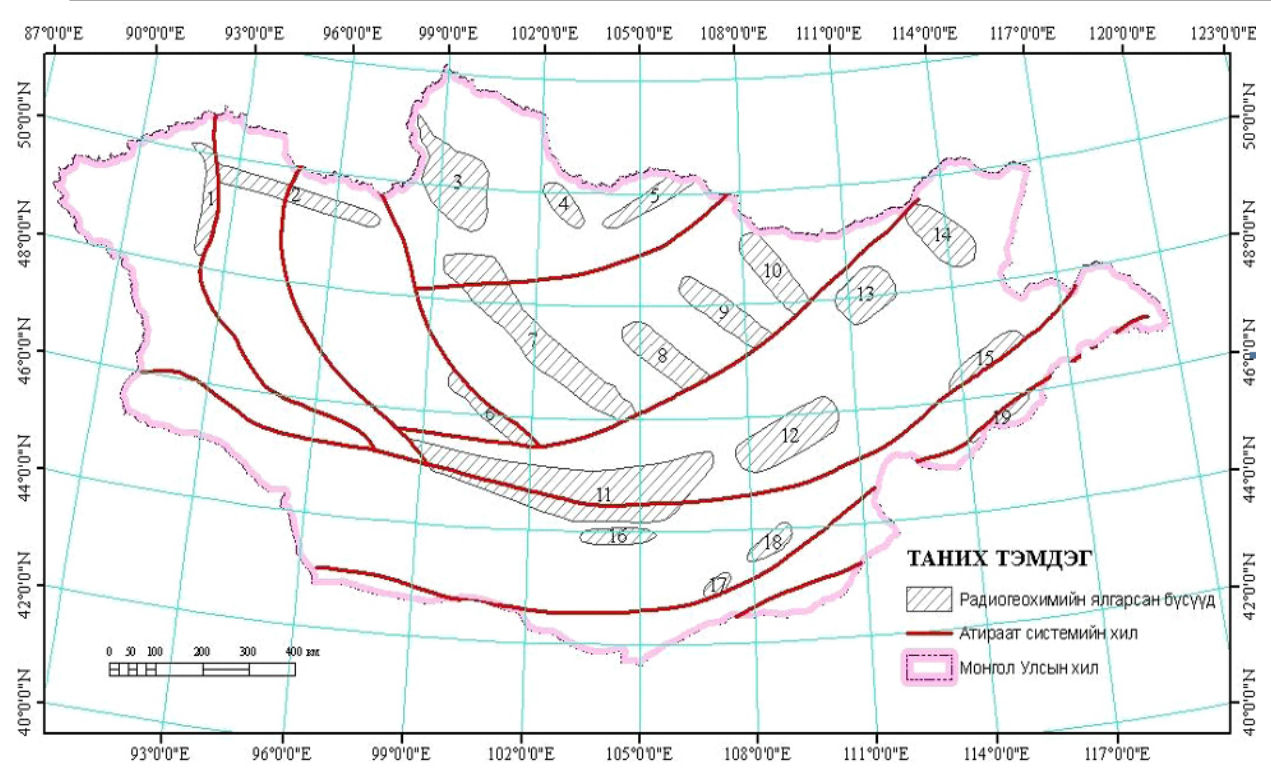

Зураг 6. Монгол Улсын нутаг дэвсгэрийн радиогеохимийн үндсэн бүсүУд (аэрогаммаспектрометрийн зураглальн материалаар Е.Е.Высокоостровская зохиов, Миронов, 2009).

1- Цагаан Шивээтийн радиогеохимийн бүс, 2- Хангайн радиогеохимийн бүс

Баруун бүс нутгийн ураны хүдэржилттэй талбайн радиогеохимийн зураг дээрх хагарлуудыг дагаж байршсан шүлтлэг гүний чулуулаг, цацраг идэвхт элементийн хуримтлал бүхий ашигт малтмалын илрэл

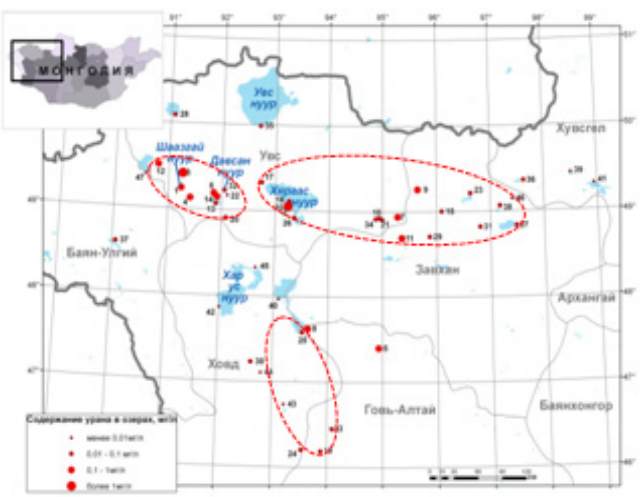

Зураг 7. Баруун Монголын Хангай ба Цагаан Шивээтийн радиогехимийн бүсийн шорвог нууруудын усны ураны геохимийн гажилийн зураг газартай уялдаатай, нууруудын усны найрлаганд уран, литийн агуулга ихсэж, тэдгээр хагарлуудыг дагаж уран, хүнцэлийн геохимийн гажилууд үүсч байгаа нь (Зураг $7,8)$ харагдана.

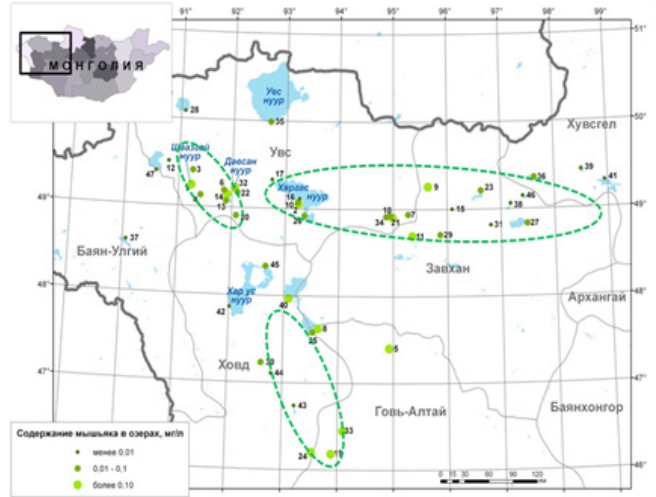

Зураг 8. Баруун Монголын Хангай ба Цагаан Шивээтийн радиогехимийн бүсийн шорвог нууруудын усны хүниэлийн геохимийн гажсильн зураг 
Хангайн ба Цагаан шивээтийн радиогеохимийн бүсэнд орших нууруудад уран ба түүнтэй геохимийн эвшил үүсгэдэг хүнцэл, литийн агуулгын хэмжээ мөн адил ихэсч байна. Эдгээр микроэлементээс гадна Хангайн радиогеохимийн бүсийн дагуу байрлалттай өндөр эрдэсжилттэй Хяргас-Айраг-Тахилт-Тэлмэн нууруудын усны агуулганд уранаас гадна селени, хар тугалга, хүнцэл зэрэг элементүүд өндөр агуулагдаж молибден илүY их хэмжээтэй хуримтлагдсан байна (Зураг 9 a,).

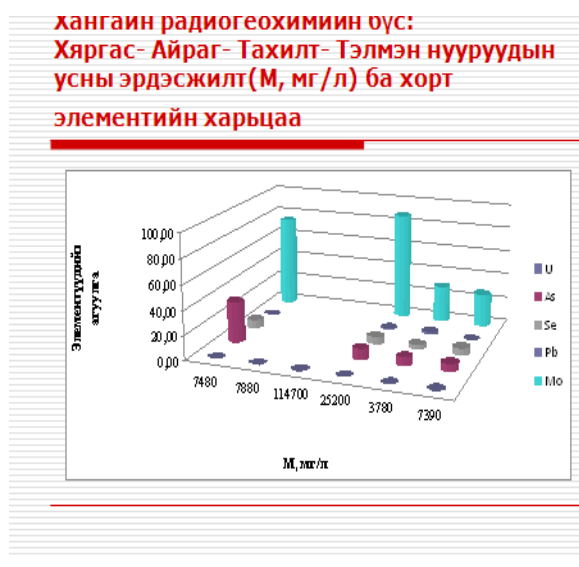

3ураг 9 a

Харин Цагаан шивээтийн хагарлын бүсийг дагасан өндөр эрдэсжилттэй Шаазгай- Давсан- Сүүж -Хар Ус-Хаг-Шар нуурын усны агуулганд молибденоос гадна хүнцэл, селени зэрэг хорт элементийн агуулга илүү их байгааг тогтоолоо (Зураг 9 б).

\section{ДҮГНЭЛТ}

Монгол, Оросын ШУА-иудын хамтарсан төслийн хүрээнд 2007-2012 онуудад явуулсан манай орны эрдэст нууруудын ус, хурдасны гидрогеохимийн судалгааны үр дүнд 50 гаруй янз бүрийн гидрохимийн найрлагатай нуурын усны эрдэсжилт, микроэлементийн шинжилгээг хийв. Энэ судалгааны үр дүнд:

1. Манай орны баруун бүсийн өндөр уулсын хооронд орших, гадагш урсаигуй, өндөр эрдэсжилттэй, хужирын найрлагатай нууруудад (Ховд аймгийн Хар $У_{с}$ нуур, Увс аймгийн Шаазгай, Хяргас г.м.) ияаираг идэвхт уран $\left({ }^{28} U\right)$ ба хорт элементүҮд ( $\mathrm{As}, \mathrm{Li}, \mathrm{Pb}, \mathrm{Se}, \mathrm{Mo})$-ийн агуулга хэвийн
Цагааншивээтийн радиогеохимийн бүс: Шаазгай-Давсан-Хар ус-Сүүж-ҮҮрэг нууруудын эрдэсжилт (М, мг/л) ба хорт элементийн агуулга

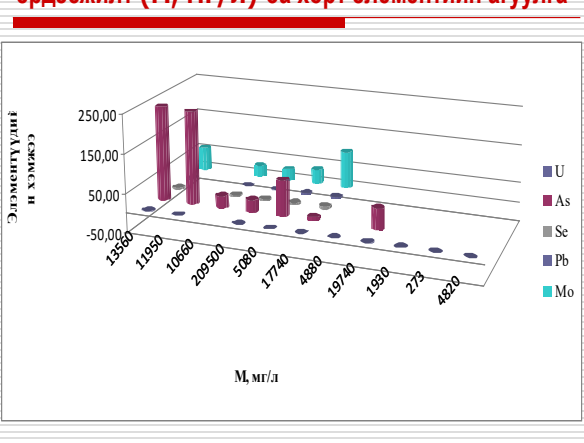

3ураг 9 б.

ҮүнээсүзэхэдЦагааншивээтбаХангайн хагарлын радиогеохимийн бүсийн дагуу орших нууруудад уран, литийн агуулга их байхын зэрэгцээ тухайн хагарлуудын дагуу байршилттай нууруудын усны дагалдах бусад хорт элементийн хэмжээ харилцан адилгүй байгааг илрүүлэв.

хэмжээнээс илҮҮ байгааг илрүулсэн. ҮҮнээс гадна зарим цэнгэг устай нуурууд болон нуурт цутгадаг булаг шанд, худагын байгалийн усанд хорт элементүүдийн агуулга мөн харьцангуй өндөр агуулагдаж байгааг тогтоов.

2. Баруун Монголын эрдэсжилттэй нууруудын уран, бусад геохимийн эвшилийн хорт элементүүдийн геохимийн гажилууд нь цацраг идэвхт элементийн хүдэржилттэй Цагааншивээт, Хангайн радиогеохимийн бүстэй давхцан байршиж байна. Иймд нуурын усны ураны агуулга түүнийг дагаж үүсдэг хорт элементүүдийн эх, Үүсвэрийг орон нутгийн ба тухайн газрын уулын 
чулуулгийн радиогехимийн фонтой харьцуулж, экологийн үнэлгээ өгөхөд ашиглах хэрэгтэй.

3. Цаашид Баруун Монголын цацраг идэвхит ба хорт элементийн өндөр агуулгатай нууруудын ойролцоо орших булаг, худагын усны, хөрс, ургамал болон хүний эрүүл мэндэд ҮзҮүлэх нөлөөллийг тогтоох зорилгоор экогеохимийн судалгааг үргэлжлүүлэх хэрэгтэй.

\section{ТАЛАРХАЛ}

2009-2010 онд Монгол,Оросын ШУА-ийн хамтарсан “Монгол Улсын эрдэст нууруудын хүдэр-хуримтлуулах боломж, тэдгээрийг ашиглах инновацийн технологи ба экологи" РФФИ-Монг_а төсөл, Монгол Улсын ШУА ба ОХУ-ын ШУА-ийн Сибирийн Салбарын хамтарсан төслийн 2011 оны санхүүжилтээр уг ажлыг гүйцэтгэв.

\section{Ашигласан бүтээлийн жагсаалт:}

1. Ариунбилэг С.,Исупов В.П., Владимиров А.Г., Кривоногов С.К., Шацкая С.С., Куйбидо Л.В. 2009. Микрокомпонентный состав минералозованных озер Восточной Монголии. Mongolian Geoscientist,Vol.35., October, p.115-116.

2. Ариунбилэг С., Исупов В.П, Владимиров А.Г, Кривоногов С.К, Шацкая С.С, Куйбида Л. В. 2009 Эрдэсжилттэй нууруудын микроэлементийн судалгаа, ШУА-ийн ГЭБХ-ийн бүтээл ${ }^{1} 19$, Улаанбаатар, х177 -180.

3. Исупов, А.Г.Владимиров, С.Л.Шварцев С.Ариунбилэг, М.Н.Колпакова, С.С.Шацкая, Л.Э.Чупахина, Л.В. Куйбида, Е.Н. Мороз.2010, Урановы ресурсы минерализованных озер Северо-Западной Монголии.// Труды ИГи МР АН М.2010, Вып.20, стр. 101-109.

4. Ариунбилэг С., Исупов В.П., Владимиров А.Г., Энхтүвшин Р. 2011. Монгол орны эрдэст нууруудын литий, ураны геохими.// Улаанбаатар,”Хайгуулчин, № 1(44),хх.129-137.

5. Исупов В.П., Владимиров А.Г., Ляхов Н.З., Шварцев С.Л., . Ариунбилэг С., Колпакова М.Н., Шацкая С.С., Чупахина Л.Э., С.Куйбида Л.В., Мороз Е.Н. 2011. Ураноносность высокоминерализованных озер Северо-Западной Монголии, Доклады Академии Наук, том 437,№1, c.85-89.

6. Шварцев С.Л., Исупов В.П., Владимиров А.Г., Колпакова М.Н., Ариунбилэг С, Шацкая С.С., Мороз Е.Н. Литий и уран в бессточных озёрах Западной Монголии// Химия в интересах устойчивого развития. 2012. Т.20, № 1. С. 43-49.

7. Исупов В.П., Ариунбилэг С, Разворотнева Л.И., академик РАН Ляхов Н.З., Шварцев С.Л., Владимиров А.Г., Колпакова М.Н., Шацкая С.С., Чупахина Л.Э., Мороз Е.Н.,. Куйбида Л.В Геохимическая модель накопления урана в озере Шаазгай Нуур (Северо-Западная Монголия) // ДАН. 2012. Т.447, № 6. С. 658-663.

8. Мөнгөнцэцэг А., Буманцэцэг Э., Бурмаа 3., Эрдэнэчимэг Г. 2011,-Баруун Монголын зарим бүс нутгийн гадаргын усны гидрохими, Улаанбаатар, х.212. 